\section{$\mathrm{Y}-12$}

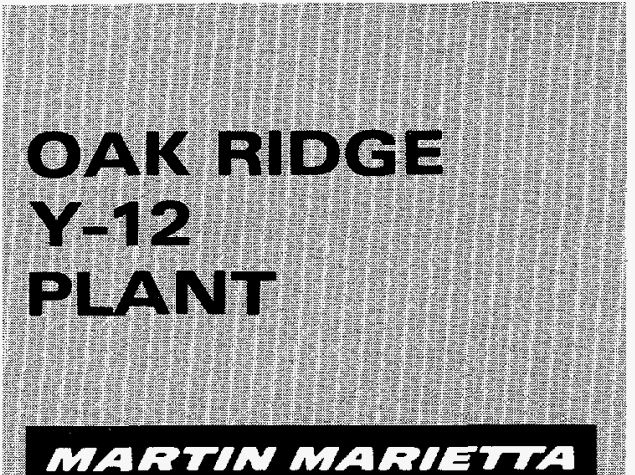

MARTUN MALUETTA

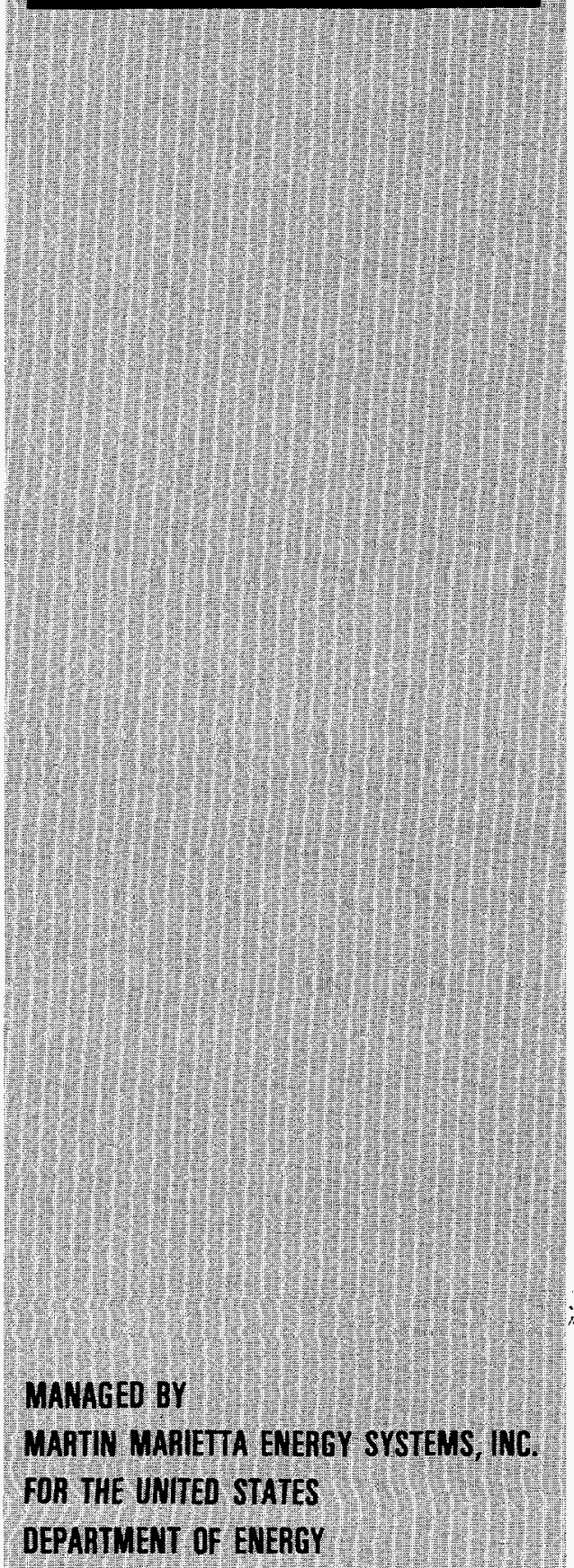

MANAGED BY

MARTIN MARIETTA ENERGY SYSTEMS, INC.

FOR THE UNTED STATES

DEPAMET Of EnERG
RECFIVED

Y/ES-044

NoV 171995

\section{OSTI \\ HIGHLY ENRICHED \\ URANIUM (HEU) STORAGE \\ AND \\ DISPOSITION PROGRAM \\ PLAN}

\author{
Prepared by \\ W. M. ARMS \\ D. A. EVERITT \\ C. L. O'DELL
}

Nuclear Materials Disposition Program Office Defense Programs

JANUARY 1995

Prepared by the Oak Ridge Y-12 Plant

Oak Ridge, Tennessee 37831 managed by

Martin Marietta Energy Systems, Inc. for the

U.S. DEPARTMENT OF ENERGY

under contract DE-AC05-84OR21400

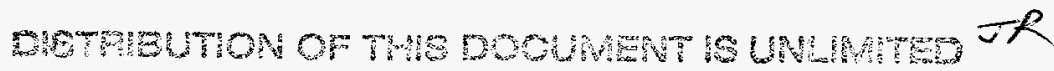




\section{DISCLAIMER}

This report was prepared as an account of work sponsored by an agency of the United States Government. Neither the United States Government nor any agency thereof, nor any of their employees, makes any warranty, express or implied, or assumes any legat liability or responsibility for the accuracy, completeness, or usefulness of any information, apparatus, product, or process disclosed, or represents that its use would not infringe privately owned rights. Reference herein to any specific commercial product, process, or service by trade name, trademark, manufacturer, or otherwise, does not necessarily constitute or imply its endorsement, recommendation, or favoring by the United States Government or any agency thereof. The views and opinions of authors expressed herein do not necessarily state or reflect those of the United States Government or any agency thereof. 
Y/ES-044

\title{
Highly Enriched Uranium (HEU) Storage and Disposition Program Plan
}

\author{
Prepared by \\ W. M. ARMS \\ D. A. EVERITT \\ C. L. O'DELL
}

Martin Marietta Energy Systems

Defense Programs

January 1995 


\section{DISCLAMMER}

Portions of this document may be illegible in electronic image products. Images are produced from the best available original document. 


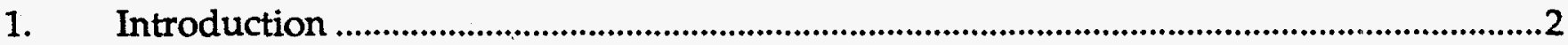

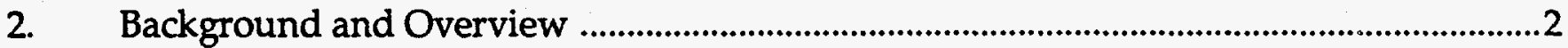

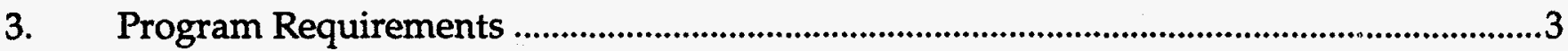

4. Organization, Roles, and Responsibilities ..........................................................................4

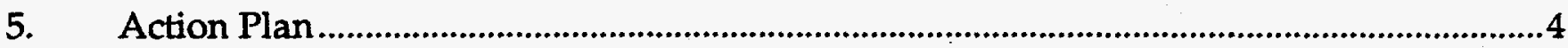

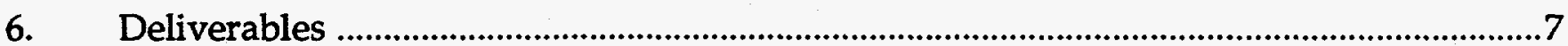

Appendix A - Long-term Storage Screening Criteria

Appendix B - HEU Blending Options Screening Criteria 


\section{Introduction}

The purpose of the Highly Enriched Uranium (HEU) Storage and Disposition Program Plan is to define and establish a planned approach for storage of all HEU and disposition of surplus HEU in support of the U.S. Department of Energy (DOE) Fissile Material Disposition Program. Elements of this plan, which are specific to HEU storage and disposition, include program requirements, roles and responsibilities, program activities (action plans), milestone schedules, and deliverables.

This HEU Program Plan is consistent with the Roadmap for Decisions Regarding Surplus U.S. Weapon Usable Highly Enriched Uranium Control and Disposition, and the Office of Fissile Materials Disposition FY95 Program Plan (FY95 Program Plan). It is a "living document" that will be updated as appropriate. The Y-12 Nuclear Materials Disposition Program Office (DPO) will manage the activities of the HEU Program and make revisions to this plan as required.

\section{Background and Overview}

Recent changes in international relations and other changes in national priorities have profoundly affected the management of weapons-usable fissile materials within the United States (US). The nuclear weapon stockpile reductions agreed to by the US and Russia have reduced the national security requirements for these fissile materials.

National policies outlined by the U.S. President seek to prevent the accumulation of nuclear weapon stockpiles of plutonium $(\mathrm{Pu})$ and $\mathrm{HEU}$, and to ensure that these materials are subjected to the highest standards of safety, security and international accountability.

In support of these national policies, the DOE has established a Fissile Material Disposition Program intended to reduce the overall quantity of weapons-usable material. DOE will prepare a Programmatic Environmental Impact Statement (PEIS) for Storage and Disposition of Weapons-Usable Fissile Materials that will evaluate alternatives for long-term storage and disposition of weapons-usable fissile materials across the DOE Complex. A Department Record of Decision (ROD) will be issued based on the results of the PEIS, public comments, and technical and cost evaluations.

The Administration's strategy for dealing with the control and disposition of surplus fissile materials consists of:

- $\quad$ securing the nuclear materials that already exist in the U.S. and Russia;

- building confidence through openness; and

- seeking to eliminate where possible the accumulation of $\mathrm{Pu}$ and HEU. 
The FY95 Program Plan outlines four major activities:

- analyzing long-term storage and disposition options for HEU;

- preparing a PEIS as required by National Environmental Policy Act (NEPA) for these options;

- integrating and documenting the results of the analysis to enable a ROD for DOE actions regarding HEU; and

- conducting outreach and public participation activities regarding surplus fissile materials disposition.

The FY95 Program Plan also presents an estimated PEIS preparation schedule with key dates as follows:

- Issue Notice of Intent - June 94

- $\quad$ Conduct Scoping Meeting - Summer/Fall '94

- Issue PEIS Implementation Plan - Winter '95

- $\quad$ Issue Draft PEIS - Summer '95

- Issue Final PEIS and enable subsequent ROD - Spring '96

3. Program Requirements

The HEU Storage and Disposition Program will support the DOE's efforts by developing options for the long term storage of all HEU and the disposition of surplus HEU. These options will be narrowed through the screening process (see Appendices A and $B$ ) and the remaining options will be analyzed to determine environmental impact, technical feasibility, cost effectiveness, IAEA inspectability, and public acceptance. This analysis will support the PEIS and the ROD and will be documented in data reports. Technical data reports will include environment, safety, and health requirements and process descriptions for each option and assessments of existing facilities or designs for upgrades and new facilities as required. PEIS data reports will provide data for proposed operations and new construction for each option including land requirements, solid and liquid wastes generated and discharged, air emissions, utilities and chemicals consumed, and employment.

All of the above must be performed in an open environment to obtain public acceptance for the ROD. Frequent public meetings will be held to keep the public and stakeholders involved and informed. The HEU Storage and Disposition Program must be integrated with the overall Department program which involves integration with other sites, DOE laboratories, DOE contractors, and the DOE Headquarters program office. 
4. Organization, Roles, and Responsibilities

The FY95 Program Plan presents the DOE Fissile Material Disposition Program Office organizational structure with program responsibilities as follows:

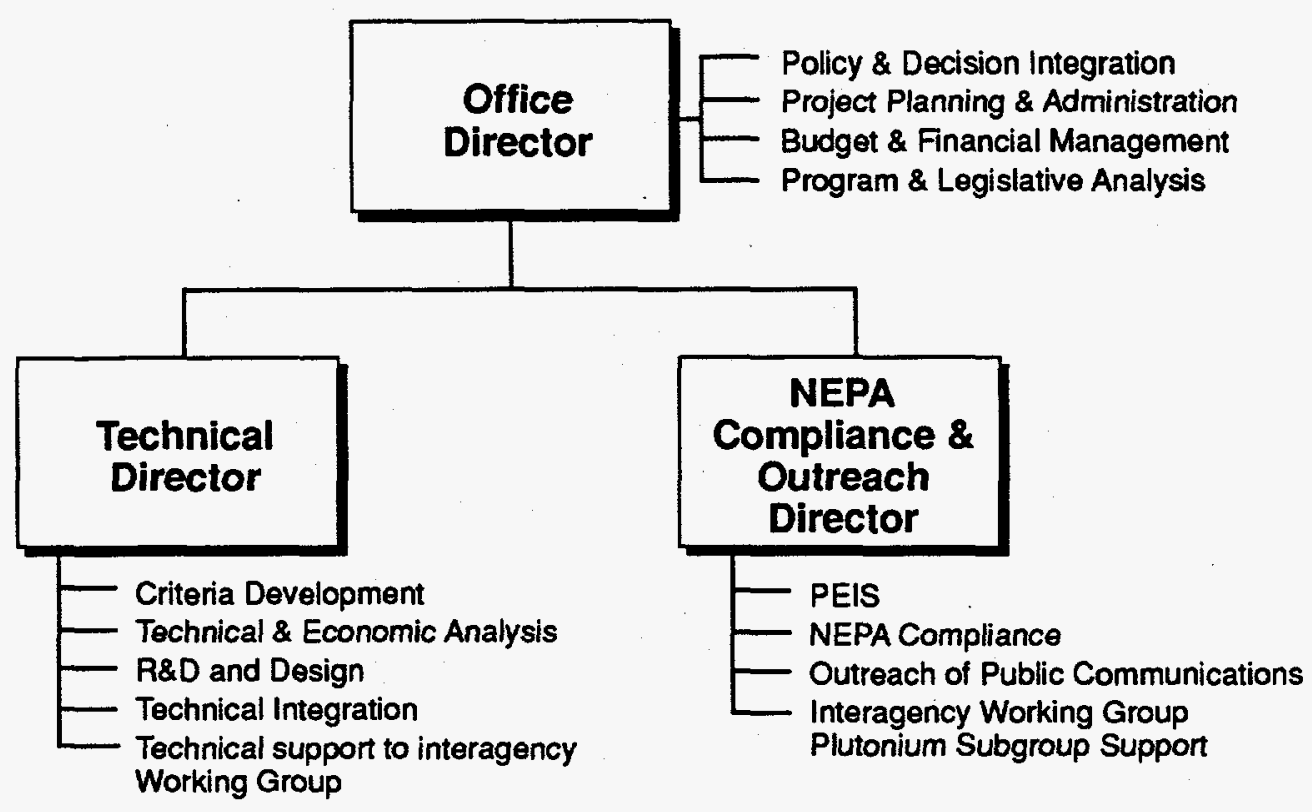

The Y-12 Plant will provide the technical lead for the HEU Storage and Disposition Program and the Y-12 DPO has been organized for this purpose. The Y-12 DPO organizational structure and interface relationships are presented in Figure 1. It highlights the many interfaces between organizations supporting the Office of Fissile Material Disposition and the matrixed relationship of the Y-12 DPO, the DOE national laboratories, and the PEIS and Architect/Engineer contractors.

5. Action Plan

Activities have been identified which support program goals and schedules. The current schedule for PEIS completion in late FY95 forces many activities to be accomplished in parallel.

a. Activities to Support HEU Storage Options

(1) Storage Quantities - Using the Nuclear Materials Management System (NMMS) database of current HEU inventories and projections for future stockpile requirements, schedules and plans for weapons dismantlement, and projections for programmatic uses, the quantity of material to be stored in FY2015 will be determined. These quantities will be categorized by type (e.g. metal, oxide, or components) to determine the type of storage required (cans vs. drums) 
Figure 1

\section{HEU Storage and Disposition Program \\ Organizational Relationship Chart}

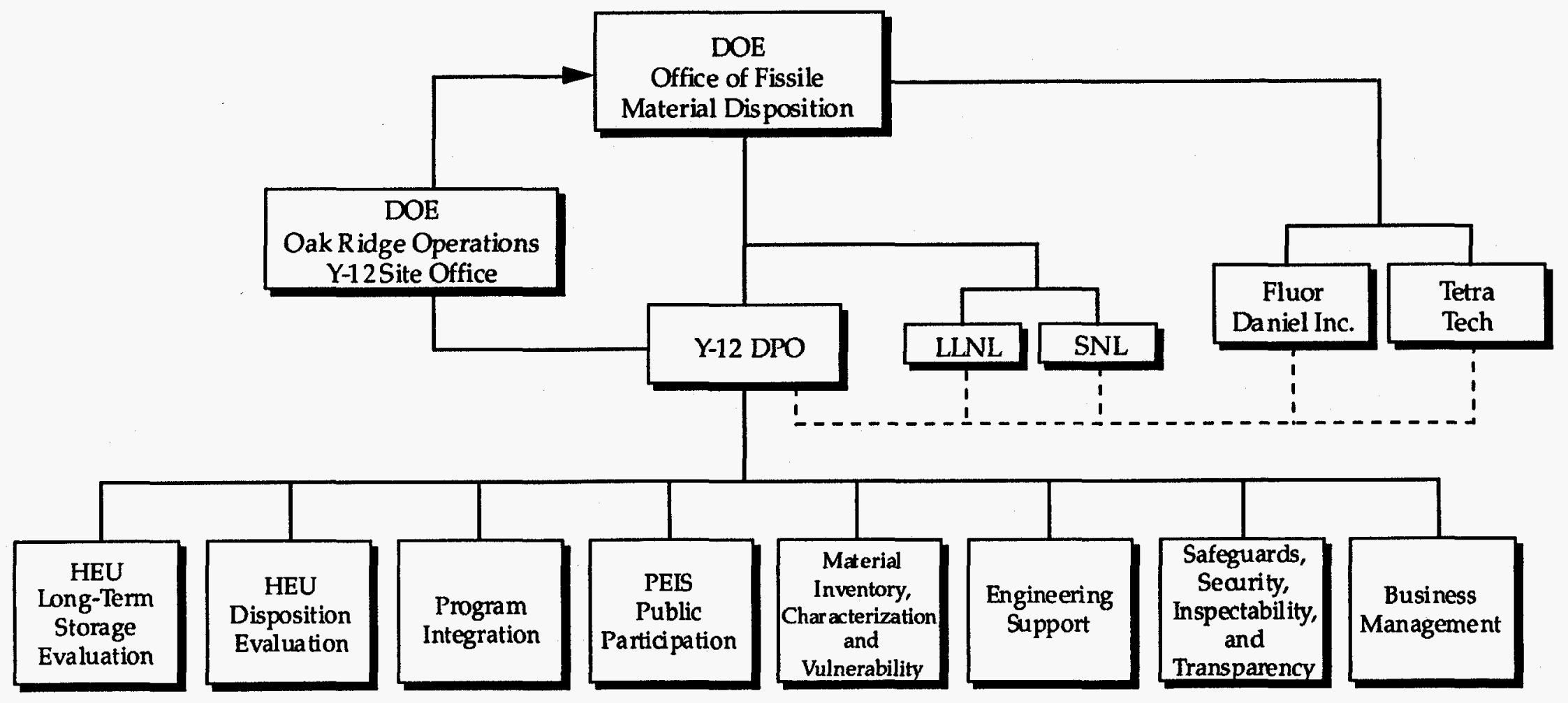


(2) Storage Criteria and Requirements - Critieria and requirements for HEU storage will be developed to assist in the design and evaluation of storage options. Included will be criteria and requirements for nuclear material control and accountability (NMC\&A), safeguards and security, criticality safety, material handling, storage array design, health and safety, and environmental compliance.

(3) Effluents from Storage Operations - Air emissions and solid and liquid wastes generated during normal storage operations will be determined as part of the overall environmental impact analysis. This data will be used for all storage options analyzed.

(4) Oak Ridge Reservation (ORR) Environmental Data - Current environmental data for the ORR will be documented and projections will be made for the No Action alternative in FY2015. This data will be used in comparing storage options against the No Action alternative.

(5) Support to Fluor Daniel, Inc. (FDI)- FDI is preparing designs, cost estimates, and environmental data for a new HEU storage facility to be located at one of five DOE sites. FDI is also preparing similar data for upgrading existing facilities within the DOE complex for HEU storage. Support to FDI includes review of block flow diagrams, equipment lists, and facility layouts. FDI will also use the results of activities 1,2 , and 3 .

(6) HEU Storage Upgrade at $Y-12$ - The $Y$-12 Plant will evaluate existing facilities currently storing HEU to determine capacity and compliance with environment, safety, and health regulations, laws, and DOE orders. Upgrade projects as required will be identified and cost estimates and environmental data will be prepared.

\section{b. Activities to Support HEU Disposition Options}

(1) Characterization of Enriched Uranium (EU) Inventory - Information about the inventory of enriched uranium has been focused historically on accounting for ${ }^{235} \mathrm{U}$. Other than ${ }^{235} \mathrm{U}$ assay this information includes storage location and material form such as unalloyed metal, alloyed metal, oxide, nitrate solution, etc. To evaluate disposition options more information is required, specifically the uranium isotopic content of the material ${ }^{232} \mathrm{U},{ }^{234} \mathrm{U},{ }^{235} \mathrm{U},{ }^{236} \mathrm{U}$, and ${ }^{238} \mathrm{U}$ ). This information is needed for the LEU inventory as well as the HEU inventory since LEU may be needed as blending material.

(2) Blending Studies - As stated in the Notice of Intent the Department's preferred option for HEU disposition is blending with either depleted, natural or low enriched uranium and to sell the resultant product to utilities for use as light water reactor (LWR) fuel. There are a number of issues for this option which can be grouped into the following categories: material issues, capability and capacity issues, and industry interface issues. A number of blending options have been 
proposed to deal with these issues. It appears that there is no single operating facility which can perform a blending operation which will satisfy all requirements. Each blending option will be studied in sufficient detail to determine technical feasibility, operating and capital costs, environmental impacts, international inspectability, and ability to interface with the LWR fuel industry.

(3) Uranium Market Analysis - Since DOE's goal is to sell down-blended HEU, determination of a market driven selling price is needed. Factors to be considered in determining price will include impact of foreign uranium, cost and supply of enrichment services, costs of fuel fabrication, world wide demand for enriched product, world wide natural uranium supply, and the role of the United States Enrichment Corporation (USEC) in marketing this material. This market analysis will provide a service to DOE in negotiating future price.

\section{Deliverables}

While additional deliverables will be identified throughout the Program, the following specific deliverables have been identified from the activities presented in the Action Plan:

\section{Deliverable}

ORR No Action Environmental Data Report

Y-12 Upgrade for Long Term HEU Storage

Criteria and Technical Requirements for HEU Storage

Preliminary Assumptions and Quantities for HEU Storage

Market Analysis for LEU from HEU

HEU Disposition Environmental Data Report

HEU Blending and Disposition Studies

HEU Transportation and Packaging Studies
Completion date

$1 / 31 / 95$

$1 / 31 / 95$

$2 / 01 / 95$

$3 / 01 / 95$

$4 / 15 / 95$

$4 / 30 / 95$

$1 / 31 / 96$

$1 / 31 / 96$ 


\section{Appendix A - Long-term Storage Screening Criteria}

Determining and analyzing the long-term storage alternatives requires the preparation and evaluation of facility designs for the long-term storage of highly enriched uranium. A screening process will be used to rule out unreasonable alternatives based on criteria initially developed by DOE and commented on by the public during the PEIS public scoping process. The long-term storage criteria are described below (the order does not reflect relative evaluation importance):

- $\quad$ Assurance Against Theft or Diversion: The site and facility must be capable of providing for comprehensive protection and control of weapons-usable fissile materials.

- Technical Viability: There should be a high degree of confidence that a facility and site infrastructure can provide storage of nuclear components and materials for at least 50 years.

- Environmental, Safety and Health (ES\&H) Compliance: High standards of public and worker health and safety, and environmental protection must be met, and significant ES\&H burdens should not be created.

- Cost Effectiveness: Long-term storage should be accomplished in a cost-effective manner, and be compatible with reasonable disposition alternatives.

- Timeliness: Long-term storage should be implemented in a time manner.

- Fostering Progress and Cooperation with Russia and Other Countries: A facility must allow international inspections, and provide a good example for achieving appropriate standards for storage and protection of international nuclear material inventories.

- Public and Institutional Acceptance: An alternative should be able to muster a broad and sustainable consensus on the manner in which long-term storage is accomplished. 


\section{Appendix B - HEU Disposition Screening Criteria}

The disposition of HEU has a very similar screening process. The criteria are described below (the order does not reflect relative evaluation importance):

- Resistance to Theft or Diversion in Procession and Storage: Each step in the disposition process must be capable of providing for comprehensive protection and control of weapons-usable fissile materials.

- Resistance to Retrieval, Extraction and Reuse: The final disposition of the surplus material must be highly resistant to potential reuse in weapons.

- Technical Viability: There should be a high degree of confidence that the alternative will be technically successful.

- Environmental, Safety and Health (ES\&H) Compliance: High standards of public and worker health and safety, and environmental protection must be met, and significant ES\&H burdens should not be created.

- Cost Effectiveness: Disposition should be accomplished in a cost-effective manner, and be compatible with reasonable long-term storage alternatives.

- Timeliness: The technology concept should be demonstrated within approximately 20 years and disposition should be completed within approximately 50 years.

- Cooperation with Russia and Other Countries: Each step in the disposition must allow international inspections, and the alternative should help support similar progress in the disposition of international weapons-usable nuclear materials inventories.

- Public and Institutional Acceptance: An alternative should be able to muster a broad and sustainable consensus on the manner in which disposition is accomplished.

- Additional Benefits: An alternative should leverage government investments for disposition of surplus materials to contribute to other national or international initiatives. 